\title{
Local People's Political Strength Supporting Dugderan Tradition
}

\author{
Tri Lestari Hadiati ${ }^{1}$, Darmawan Tri Budi Utomo ${ }^{2}$ \\ \{liestarihadiati@gmail.com ${ }^{1}$, tbudarmawan12@gmail.com² ${ }^{2}$, \\ Universitas 17 Agustus 1945 Semarang, Indonesia ${ }^{1,2}$
}

\begin{abstract}
The Kauman community in the city of Semarang in Central Java province is known to have its own independence and political power to maintain their environment. The Kauman community, by its mean, tries to preserve their ways of earning for living, which include maintaining its cultural tradition "Dugderan Tradition" so that it does not become extinct. But the city government until now has not made the Kauman community as a unique indigenous community with its dugder tradition in the city of Semarang. The city government has given less political and economic support to the people of Kauman. Therefore, at the people side, this condition has greatly disappointed them. Such conditions, led to the emergence of a group or several groups or institutions that have political power (multi-power) in order to negotiate and bargain (bargaining power) with the city government, especially to maintain the place of life and integrity of the Kauman people's Dugderan traditions from extinction. This research is intended to gain knowledge about the political power of a group of people's elite in the context of local government in Indonesia. The main purpose of this research is to find out what political power is owned by the Kauman community, so that it can sustain the pressure of the government and the market, who took over the management of The Dugderan Tradition. This research method used survey methods and types of qualitative research. In-depth interviews were conducted by asking informants to conduct in-depth interviews several times. General observation and in-depth interviews were then analyzed to find information and the context of the political power needed. Firstly, the results of this study found new things related to the Kauman elite community ways - supported by multiple power, which succeeded to preserve their place of life and cultural Dugderan traditions. This means that the people are able to develop their own independent political forces maintain the Dugderan tradition because they are pressed by primary needs. Secondly, modernization makes the Kauman community more emending and they are more involved in the government's political decision especially in terms of building, maintain the Dugderan and developing the Kauman Area.
\end{abstract}

Keywords: Political Power, Multiple Power, Super Power, The People of Kauman, Dugderan Tradition, The Development of The Kauman Region

\section{Introduction}

Major changes have taken place in Indonesia, especially dealing with the involvement of the people in political decision making. This can be seen in the implementation of the presidential Election (Pilpres), the system of electing regional heads (Pilkada) and the legislation (Pileg) member of election board, which is the chain of political reforms to realize democratic politics in Indonesia. The ideal goal of electing political leaders is to bring the 
leader elite to the people he leads, where every citizen who ages 17 years or older or married has the right to vote in the general election (Election).

Communities with an advanced democratic system, such as civil society or later can be called the people play a role not to govern or carry out political decisions of elites. But on the contrary it is precisely the people who demand political power in the general election which has the role to produce a government that is the mediator to carry out the decisions of the people who have chosen it.

Civil society is a political force that is independent and they have the power or energy including high spirit to maintain its existence.

In turn, political decisions that are communal between the executive elite and the legislative elite aim to fulfill the people's aspirations according to the primary, secondary and tertiary needs of the people instead of fulfilling the needs of the political elite alone. The elite can in turn accept the people's arguments, and vice versa, the people can be a volunteer and un-pressured to accept the aspirations and arguments of the elite government.

\section{Theoretical Framework}

The discussion of this study uses the point of view of the Political Power Theory taken from the Elite Mass Theory of Schumpeter [1], and the Civil Society Theory of Edwards [2]. These theories are selected to be used to analyze problems (as the problem formulation) because after reviewing, comparing and searching for models, those theories best suit the needs of the field and analysis of the researcher, who took over the management of the Dugderan tradition.

\subsection{Statement of the Problems}

This research is intended to analyze the magnitude of the political power of one group of elite people in the context of local government in Indonesia. Then, this study also want to analyze the political power side of the Kauman elite community [3][4], so that it can preserve the pressure of local elite government and markets.

\subsection{Significance of the Study}

Stephen's study on Domination and Limitations of Elite Influence on Democratic Theory, suggest the importance of democratic practice, he shows that citizens are actually able to make policy assessments of the benefits of the policies implemented, so that the citizens are not always in a position to support the policy [5] By means of political deliberation and the establishment of an open public space, it turns out that citizens (the Kauman elite community) are able to fulfill the most basic tasks, they can assess government policies, which is not wise.

Stephen's study also indicates that citizens will not follow the elite if they see them acting contrary to their beliefs. This shows that the credibility and trust of citizens is important for the elite [5].

Likewise, the results of Lipuma's research [6] in South Africa, explained that although the position of the community is generally weak against elite leadership, because of the lack of political deliberation in South Africa. Citizens (the Kauman elite community) have their own 
willingness and needs that must be met. And they continue to struggle to achieve the fulfillment of these needs.

In other studies, as well as a modern and democratic Korean state capable of maintaining the traditions of its citizens, the Kauman elite community also seems to be able to maintain its dugder tradition. Meanwhile in Chile the attention of the government is also not much different, including differences in the way the dugderan tradition is managed. Siavelis [7] sees that there is a level of compatibility between the views of the elites in Chile, by categorizing Chile as a successful democracy and having good attention to its mass conditions. The study of the importance of matching views between the elites, begins with the old idea that elite preferences that are equal to the people in various political deliberation activities will be very useful.

Democracy requires more than just deliberation, agreement, understanding about orientation and issues. It also requires legitimacy, accountability, change of power, and a feeling that participation in elections makes differences between elites and people respected. Siavelis's research [7] argues that many gaps between the elite and the people, Elite continues to try to implement and operate a democratic transition model, in this study the management of the more modern dugderan traditions. While citizens demand a new system that is better, not only good for the elite but good for the citizens, that is the dugderan tradition management system which is more classic/typical of old traditions. A better model of democratic transition is on the steps of accountability and legitimacy, which affect the outcome of decision making.

But Indonesia is democratic, and especially the local government of the city of Semarang, is not immune from popular dissatisfaction which demands a better quality of democratic function, which does not disturb most (the Kauman elit community) citizens, as in general there is always an elite-mass mismatch.

\section{Research Methodology}

Researchers selected the type of qualitative approach research to examine all the problems. It is to find a phenomenon of civilian political power that has unique characteristics in detail and depth about everything [8] which relates to the implementation of Dugderan in Semarang City, Central Java. The unique phenomenon refers to cases of public bargaining (bargaining power) and government elites, in the implementation of the Dugderan market in the Kauman area.

The main instrument in this study is the researcher himself as reviewed by Miles and Huberman [9]. The researcher is to support qualitative data obtained from informants (primary informants, secondary informants and supporting informants). Researchers added an interview with special speakers (academics) such as Prof. Nurdin H. Kistanto and Prof. Djuliati Suroso.

These informants were expected by researchers to recount their involvement as civil society [10] in the organization of Dugderan. While the speakers were also expected to be able to provide insight and depth of research on the implementation of this Dugderan bargaining power. 


\section{Finding and Discussion}

In the civilized life of Semarang people, there are some typical religious rituals that were carried out as obligatory rituals in their respective religions and eventually became the tradition of Semarang people. There are $83.43 \%$ Muslim population of the entire population in the city of Semarang, based on the data from Semarang 2017 Pocket Book, Semarang City BPS, p. 118. Some of them preserve the local traditions such as Slametan, Yasinan, Takbiran, Khataman, Khitanan, and Dugderan. The tradition of Dugderan Celebration [11], is a celebration that is almost followed by some people of the city of Semarang. The supporters and conservationists of this tradition are the people of Kauman who live in the District of Central Semarang [12]. This Kauman people live around Kauman Semarang Mosque (MAS) or called Kauman Mosque which is located in Kauman street [13].

The Dugderan celebration is an opportunity for the people to celebrate every year before the fasting month of Ramadhan. This celebration was preceded by the emergence of the Dugderan Market a few days to one week before the Ramadan fasting [14]. Then it was followed by the tradition of Warak Ngendhog festival one day before the fasting at the first of Ramadhan [15] and ended with the reading of Suhuf Halaqah, the distribution of the Gunungan (an offering) which contains bread named Ganjel Rel and the Qataman Al Quran at the Procession of Dugderan in the final series of Dugderan Celebrations [16].

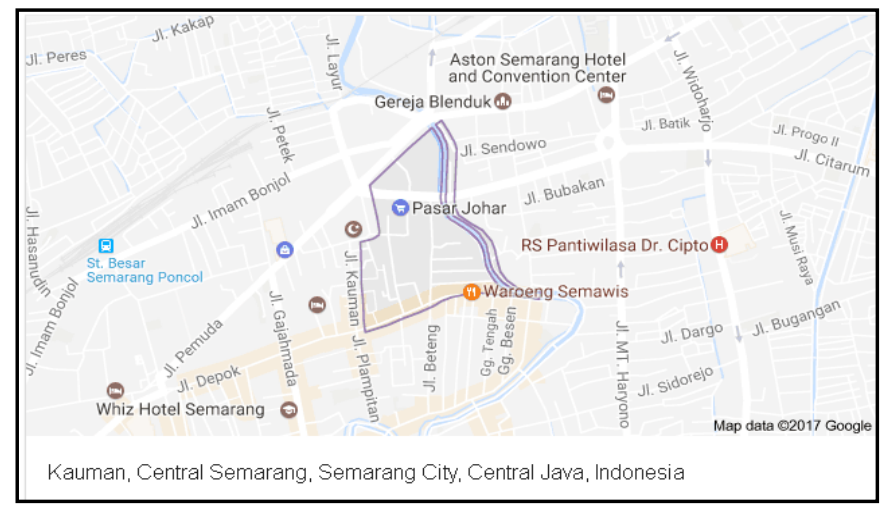

Fig. 1. The Map of Kauman Kampong in Semarang City 2017.

\subsection{The Civilians of Semarang City}

According to the theory of Edwards in his book Civil Society [2], civil society can correct mistakes made by the state and the market. The civil society in this study is also called the people, especially the Muslim people in the city of Semarang, amounting to $83.43 \%$, who have succeeded in correcting the mistakes that have been made by leaders Semarang city in the past.

Civil society (the Kauman elite community) is a special product of relations between the state and capitalism that grows spontaneously, in order to mediate conflicts between social and economic life [17]. Civil society exists as (1) a public space that was born along with industrialization of the 20th century, and (2) the people of the city of Semarang, especially the 
people of Kauman in the Central Semarang region. The society had mediated the conflict dealing with Dugderan celebration [18].

Edwards simplifies Civil Society as associational life [2]. Civil society, in the city of Semarang or it is also called as Wong Semarang, means all associations and cooperation networks where members and activities are voluntary, and as non-governmental organizations consist of various associations such as workers or labor units, political parties, other religious groups, professionals and business associations, community of citizens, social groups and independent media.

But in this study the definition of Civil Society as associational life is a humanitarian association (the Kauman elite community) which is formed because of the needs of Muslim families for the knowledge and implementation of the beginning of Ramadhan month. Muslim people in the society felt a failure to fulfill the need to practice religion and religious beliefs calmly, and religious interests by conducting Dugderan Celebration once a year in Semarang.

Civil Society as the good society according to Edwards [2] means a society that forms goals and means to achieve that particular intention. In Semarang city, there were $83.43 \%$ Semarang people (Wong Semarang), with the Semarang city government and businessmen from various different interests [19]. Had compromised to achieve their goals to achieve best strength and outlook in organizing Dugderan celebrations, in contemporary political life and in collective action [20].

Civil Society as the public sphere according to Edwards becomes an arena where community groups play an important role in social change [2]. The civil society that happened to the Kauman elite community in the city of Semarang depicts all people (character: M Djawahir, Muhaimin, Ahmad Wahid) who care about the common good and have the capacity to democratically discuss the things and problems of the society. This means that the society works in a framework of monitoring public thinking in a public space [18]. Civil society in the city of Semarang in general and Muslim people (the Kauman elite community) in particular is a form of new public space seen in the 20-21 century.

\subsection{Political Power of Kauman People}

Looking at the implementation of Dugderan in the city of Semarang it can be said that it is true what Schumpeter [1] and Weber [21] said, which emphasized that democracy is in fact despite the principles of government by the people, but its practices are governed by elites.

This can be seen from the practice of implementing Dugderan in the city of Semarang before 2004. For almost 30 years ago, (since 1975) Dugderan was moved to City Hall. It was set by the Semarang political elite (Hadijanto, Imam Soeparto, Soetrisno Soeharto) at that time in order to centralize its implementation at City Hall [22][23]. It was only in 2004 that the government elite (Sukawi Sutarip, Soemarmo, Hendar Prihadi) were moved to the Kauman Mosque.

Table 1. The Mayor of Semarang and His Government Period

\begin{tabular}{clc}
\hline No. & \multicolumn{1}{c}{ The Mayor of Semarang } & Period \\
\hline 1 & Mr. Moch. lchsan & $1945-1949$ \\
2 & Mr. Koesoedibiyono Tjondrowibowo & 1949-1 July 1951 \\
3 & RM. Hadisoebeno Sosrowerdoyo & 1 July 1951-1 January 1958 \\
4 & Mr. Abdulmadjid Djojoadiningrat & 7 January 1958-1 January 1960 \\
5 & RM Soebagyono Tjondrokoesoemo & 1 January 1961-26 April 1964 \\
6 & Mr. Wuryanto & 25 April 1964-1 September 1966 \\
7 & Letkol. Soeparno & 1 September 1966-6 March 1967 \\
8 & Letkol. R. Warsito Soegiarto & 6 March 1967-2 January 1973
\end{tabular}




\begin{tabular}{clc}
9 & Kolonel Hadijanto $*$ & 2 January 1973-15 January 1980 \\
10 & Kol. H. Iman Soeparto Tjakrajoeda SH* & 15 January 1980-19 January 1990 \\
11 & Kol. H. Soetrisno Suharto* & 19 January 1990-19 January 2000 \\
12 & H. Sukawi Sutarip SH** & 19 January 2000-2010 \\
13 & Drs. H. Soemarmo HS, MSi.** & $2010-2013$ \\
14 & Hendrar Prihadi, SE, MM.** & $2013-2015$ \\
15 & Hendrar Prihadi, SE, MM.** & $2015-2019$ \\
\hline
\end{tabular}

Source: https://id.wikipedia.org/wiki/Kota Semarang, accessed December 23, 2016.

Information:

*The Mayor of Semarang held the Dugderan Procession at City Hall

** The Mayor of Semarang held a Dugderan Procession at the Kauman Mosque

Zavediuk [24] in his study of the practice of deliberative theory, mentioned that in the practice of deliberative theory, there is actually no firm line that separates political knowledge from the ignorance of political knowledge owned by the community. For instance, it is about how much is the threshold of political knowledge in general that must be exceeded to be able to engage in political decision making. Furthermore, Zavediuk [24] said that even though in the deliberation process, all communities are all educated, both formally, possessing information that is very adequate and they are fully rational, have strong individual motivation, but still the problem of individual and community political ignorance continues.

This could have happened in the condition of "silence" of the people for 30 years, when he saw the practice of Dugderan implementation in the city of Semarang before 2004, so before for almost 30 years (since 1975) was moved from City Hall.

There were (1) a number of individuals and communities who do not have enough knowledge to choose and sort information and gather various accurate information about the practice of Dugderan implementation in the city of Semarang before 2004 [16][25][26]. (2) a number of individuals and communities in the city of Semarang who have never had enough knowledge to vote in various elections in the right way (elections before the reform era, namely the New Order era with a quasi-democratic electoral system lasting 32 years). Those types of individual gave impact to constituency and structural problems of individual ignorance and the community itself [27].

According to Schumpeter [1], what classical theorists call "the will of the people" is actually just the result of the political process, instead of the spirit or driving force. In other words, democracy only means people have the opportunity to reject or accept the decisions of elites who will rule them [7][28].

At this point it was found that the local people the Kauman elit community represented by Muhaimin, Ahmad Wahid \& Jawahir Muhammad's Jamaah Peduli Dugder-JPD (The Followers of Dugderan Care) was a multi-power [29], independent, independent and strong people's political power to maintain the existence of Dugderan [18]. In 2004 the JPD community only realized and had the opportunity to conduct political deliberations with the political elites of the Semarang city government. Local people have the opportunity to reject the decisions of elites who will govern them [30][5], to carry out the Dugderan Celebration in the city of Semarang at City Hall as in previous years, namely since 1975 the Semarang Regency pavilion was demolished and moved to City Hall.

The Dugderan celebration in the city of Semarang finally, after the people could carry out political deliberations with the government, there was a definite decision to determine the location of the Dugderan Celebration in the city of Semarang. The government elites and the people [31], then decided to return the Dugderan incident centered on the Kauman mosque in 
Semarang. As in the beginning, Semarang Regent, RMT Ario Purboningrat in 1881-1897 [2][8] did it with religious leaders in the Kauman mosque in Semarang [33][34].

\section{Conclusion}

Firstly, this study found that the discovery of dynamic civilians who had multi-power, were the elite people of Kauman and the surrounding community.

Secondly, this study found political actors who played a role in social change and were supported by the prevailing power structure conditions. Here important political actors who made social changes and tried to influence the power structure of leaders in the city of Semarang, so far were the leaders of the Kauman people and leaders of the community lovers, supporters and conservationists of the tradition of the Dugderan Celebration in the vicinity, represented by elites of political leaders. Kauman mosque (Muhaimin, Ahmad Wahid), Jamaah Peduli Dugder-JPD (M Djawahir), and the Market and Service Traders Association PPJP (Mudasir, Tobari) in Central Semarang District.

Thirdly, there was a role of the elite political actors to determine political decision making in the current democratic system. At the time of this research, the government administration, Semarang Mayor, Hendar Prihadi's era (2015-2019). The prevailing government system was a decentralized government system. In this study, therefore the enactment of the Autonomy of the Regional Government has become very instrumental, especially the regional elites such as mayors (Sukawi Sutarib, Soemarmo, Hendar Prihadi), Bappeda and elite bureaucrats from agencies, including members of the Semarang city council in carrying out political decision in Dugderan Celebration dealing with timing, process and its location.

\subsection{Acknowledgement}

The researcher expresses his gratitude for the financial support from the Ministry of Research, Technology and Higher Education in 2018. Likewise, other moral and material support from the University of 17 August 1945 Semarang since the research in early 20162018. Researchers also expressed they're thanks to Prof. Nurdin H Kistanto, PhD, Prof. Dr. Naili Farida, M.Si and Prof. Budi Setiyono, $\mathrm{PhD}$ as promoter and promoter 1 and co-promoter 2.

\section{References}

[1] J. A. Schumpeter, "How does one study social science?," Society, vol. 40, no. 3, pp. 57-63, 2003.

[2] M. Edward, Civil Society. USA: Polity Press in association with Blakckwell Publishing Ltd, 2008.

[3] A. Budiman, Semarang juwita: Semarang tempo doeloe, Semarang masa kini dalam rekaman kamera, vol. 1. Tanjung Sari, 1979.

[4] A. Budiman, Semarang riwayatmu dulu. Tanjung Sari, 1978.

[5] S. P. Nicholson, "Dominating cues and the limits of elite influence," J. Polit., vol. 73, no. 4, pp. 1165-1177, 2011.

[6] E. LiPuma and T. A. Koelble, "Social capital in emerging democracies," Volunt. Int. J. Volunt. 
Nonprofit Organ., vol. 20, no. 1, p. 1, 2009.

[7] P. M. Siavelis, "Elite-mass congruence, partidocracia and the quality of Chilean democracy," $J$. Polit. Lat. Am., vol. 1, no. 3, pp. 3-31, 2009.

[8] C. John W., Qualitative Inquiry and Research Design : Choosing Among the Five Approaches. 2013.

[9] M. B. Miles and A. M. Huberman, “Analisis Data Kualitatif.” Jakarta: UI press, 1992.

[10] H. Antlov, D. W. Brinkerhoff, and E. Rapp, "Civil society organizations and democratic reform: Progress, capacities, and challenges in Indonesia," in RTI International, Paper presented at the 37th Annual Conference, Association for Research on Nonprofit Organizations and Voluntary Action, Philadelphia, 2008, pp. 20-22.

[11] A. Cahyono, "Seni Pertunjukan Arak-arakan dalam Upacara Tradisional Dugdheran di Kota Semarang (Arak-arakan Performing Art of Dugdheran Tradisional Ceremony in Semarang City)," Harmon. J. Arts Res. Educ., vol. 7, no. 3, 2006.

[12] N. Azizah, "Perubahan Sosial, Budaya Dan Ekonomi Di Kampung Kauman Semarang 19621998." Universitas Negeri Semarang, 2015.

[13] N. H. dkk Kistanto, "Pesona Budaya Jawa Tengah," Pemerintah Provinsi Jawa Teng., 2006.

[14] R. Kurniati, "Upaya Pelestarian Kampung Kauman Semarang sebagai Kawasan Wisata Budaya," Tek. PWK (Perencanaan Wil. Kota), vol. 2, no. 2, pp. 208-222, 2013.

[15] M. Z. Mawahib, "Kebudayaan Masyarakat Semarang; Warak Ngendok sebagai Simbol Akulturasi dalam Tradisi Dugderan Menjelang Ramadhan," E-Journal Elsaonline.Com, 2015.

[16] M. Djawahir, "Semarang Dalam Lintasan Sejarah dan Budaya," Serial Semarangan (1-8), Harian Suara Merdeka Semarang, 2013.

[17] L. H. Tri, "Political Discussion Trough Dugderan Celebration (Case Study of Political Cultural in Semarang City)," IJRDO-Journal Soc. Sci. Humanit. Res. Haryana India, vol. 2, no. 11, 2017.

[18] L. H. Tri, "Deliberasi Keputusan Politik Perayaan Tradisi Dugderan Di Kota Semarang," Desertasi S3, Prodi Dr. Ilmu Sos. Ilmu Polit. UNDIP, Semarang, 2018.

[19] J. Bertrand, Nasionalisme dan Konflik Etnik di Indonesia. Yogyakarta: Ombak, 2012.

[20] D. Held, Models of democracy. Stanford University Press, 2006.

[21] M. Weber, Economy and society: An outline of interpretive sociology, vol. 1. Univ of California Press, 1978

[22] S. P. B. Kasturi, Dugderan Dari Masa ke Masa. Semarang: Disbudpar Kota, 2010.

[23] B. G. Bishin, R. R. Barr, and M. J. Lebo, "The impact of economic versus institutional factors in elite evaluations of presidential progress toward democracy in Latin America," Comp. Polit. Stud., vol. 39, no. 10, pp. 1194-1219, 2006.

[24] N. Zavediuk, "Review of Democracy and Political Ignorance: Why Smaller Government is Smarter by Ilya Somin (Stanford, CA: Stanford University Press, 2013),” J. Public Delib., vol. 10, no. 2, p. 4, 2014.

[25] B. A. Suprapti, E. Budihardjo, N. H. Kistanto, and A. E. Tungka, "Ethnography-Architecture in Kampong Kauman Semarang: A Comprehension of Cultural Toward Space," Am. J. Eng. Appl. Sci., vol. 3, no. 3, 2010.

[26] T. Triyanto, N. Rokhmat, and M. Mujiyono, "Warak Ngendog: Simbol Akulturasi Budaya pada Karya Seni Rupa," Komunitas Int. J. Indones. Soc. Cult., vol. 5, no. 2, p. 168804, 2013.

[27] P. Bernhagen and H. Schmitt, "Deliberation, political knowledge and vote choice: Results from an experiment with second-order elections," Eur. Union Polit., vol. 15, no. 3, pp. 352-371, 2014.

[28] P. Wayne, "Public Policy: Pengantar Teori dan Praktik Analisis Kebijakan," Jakarta: Kencana, 2006.

[29] R. A. Dahl, Who governs?: Democracy and power in an American city. Yale University Press, 2005.

[30] G. Domhoff, The Power Elite and The State: How Policy is made in America? New York: Aldine de Gruyter, 1990.

[31] J. S. Davidson, D. Henley, and S. Moniaga, Adat dalam Politik Indonesia. Yayasan Pustaka 
Obor Indonesia, 2010.

[32] J. Tio, Semarang City, a glance into the past. Jongkie Tio, 2007.

[33] A. F. Yusuf, "Melacak Banda Masjid yang Hilang," Semarang Aneka Ilmu, 2000.

[34] T. Suliyati, "Dinamika Kawasan Pemukiman Etnik di Semarang," Makal. pada Semin. Perkemb. Kota Semarang Dalam Perspekt. Sej., 2011. 